\title{
Clinicopathologic Significance of SATB1 and DJ-1 Proteins Expression in Cervical Carcinoma
}

\author{
Ashraf Ishak Fawzy Tawadros ${ }^{1 *}$ and Mohamed Mohamed Mohamed Khalafalla ${ }^{2}$ \\ ${ }^{1}$ Pathology Department, Faculty of Medicine, Minia University, El Minia, Egypt \\ ${ }^{2}$ Obstetrics and gynecology Department, Faculty of Medicine, Menofia University, Menofia, Egypt
}

\begin{abstract}
Background: Special AT-rich sequence binding protein 1 (SATB1) and DJ-1 proteins play a crucial role in tumorigenesis and tumor progression in many human malignancies. Limited data is available in literature about their role in cervical carcinomas.

Aims: The present study was designed to investigate the immunohistochemical expression of SATB1 and DJ-1 proteins in cervical carcinoma and their relationships to clinicopathologic variables.

Material and Methods: Tissue sections from 100 cervical lesions distributed as 60 cases of cervical carcinoma, 30 cases of squamous intraepithelial lesion (SIL) and 10 cases with normal cervical tissue were evaluated for SATB1 and DJ-1 proteins expression by immunohistochemistry.

Results: SATB1 expression was detected in $41.7 \%$ of cervical carcinomas versus $20 \%$ and $6.7 \%$ of HSIL and LSIL, respectively ( $p=0.019$ ). A significant positive correlation between SATB1 expression to lymph node metastasis $(p=0.004)$ and $p$ TNM $(p=0.028)$ was noted. DJ-1 expression was detected in $68.3 \%$ versus $33.3 \%$ and $13.3 \%$ of HSIL and LSIL, respectively $(\mathrm{p}=0.001)$. A significant positive association between DJ-1 expression and lymph node metastasis $(\mathrm{p}=0.037)$ was noted. Normal cervical tissue was negative for SATB1 and DJ-1 expression. A significant positive association between SATB1 and DJ-1 immunoreactivity was detected in investigated cervical carcinomas $(\mathrm{p}=0.027)$.

Conclusions: SATB1 and DJ-1 are shown to be promising potential prognostic biomarkers in cervical carcinoma since their overexpression is correlated with advanced clinicopathologic variables including lymph node metastasis. SATB1 and DJ-1 can be promising therapeutic targets for cervical cancer.
\end{abstract}

Keywords: Cervical Carcinoma, SATB1, DJ-1, Immunohistochemistry, Clinicopathologic Variables.

\section{Introduction}

Cervical cancer is the fourth most commonly diagnosed cancer in women worldwide and the fourth leading cause of cancer-related mortality. The majority of cervical cancer deaths occur in developing countries due to tumor diagnosis at advanced stages..$^{[1]}$ Squamous cell carcinoma is the most frequent histologic subtype, accounting for $\sim 90 \%$ of cervical cancer cases..$^{[2]}$ Several molecular mechanisms underlie the progression of cervical cancer; hence understanding these mechanisms is an important target in predicting the prognosis and controlling the progression of such cancer.

Special AT-rich sequence binding protein 1 (SATB1) is a tissue-specific nuclear matrix binding protein that was originally described as $\mathrm{T}$ cell enriched transcription factor that regulates many genes involved in $\mathrm{T}$ cell development and differentiation. ${ }^{[3,4]}$ SATB1 gene is located on the third chromosome (3p23) in humans. ${ }^{[4]}$ SATB1 functions as a global chromatin organizer involved in regulation of large number of genes by selectively tethering their regulatory regions and via formation of a characteristic cage-like structure around the heterochromatic regions. ${ }^{[4,5]}$ Under normal physiological conditions, SATB1 is highly expressed in the thymus and its expression is virtually undetectable in other tissues except for low levels in testis, fetal brain, and osteoblasts. ${ }^{[3]}$ Recent studies in the last few years have shown overexpression of SATB1 in a variety of malignant tumors including cutaneous malignant melanoma, breast, gastric, colorectal and laryngeal carcinomas where it is linked to tumor progression and metastasis. ${ }^{[6]}$

DJ-1(PARK7) is an oncogene mapped at chromosome 1p36.2-p36.3, a locus known to be hot spot of chromosome aberrations in several cancers. ${ }^{[7]} \mathrm{DJ}-1$ protein is widely expressed in various human tissues, with high expression levels in testis, kidney, pancreas, heart and skeletal muscle. ${ }^{[8]}$ It is involved in diverse biologic processes such as cell migration, cell adhesion, apoptosis, chemotaxis, transcriptional regulation, antioxidant stress function, mitochondrial regulation and fertilization. ${ }^{[8,9]}$ DJ-1 protein overexpression has been reported in a variety of malignant 
tumors including breast, prostate, ovarian, hepatocellular, pancreatic, renal and non-small cell lung carcinomas. ${ }^{[7,9,10]}$ Very limited data is available in the literature regarding both SATB1 and DJ-1 expression in cervical cancer. Also present are conflicting reports about subcellular localization of DJ-1 protein expression detected by immunohistochemistry.

The present study was designed to investigate the immunohistochemical expression of SATB1 and DJ-1 proteins in cervical carcinoma, their relationships to clinicopathologic variables as well as to each other. Also targeted was highlighting biomarkers expression in cervical squamous intraepithelial lesion (SIL) as well as normal cervical tissue.

\section{Materials and Methods}

Study Design: The present study was carried out on paraffin blocks of formalin-fixed tissue sections of 100 cases distributed as 60 cases of cervical carcinoma, 30 cases of squamous intraepithelial lesion (SIL) and 10 cases with normal cervical tissue. Cancer specimens included 53 squamous cell carcinomas and 7 adenocarcinomas while SIL specimens included 15 low-grade squamous intraepithelial lesion (LSIL) and 15 high-grade squamous intraepithelial lesion (HSIL). These specimens were retrieved from the archives of Histopathology Lab of Department of Pathology, Faculty of Medicine, Minia University, Egypt. Cancer specimens were collected consecutively during the period from January 2008 to December 2016 and obtained from patients undergoing surgical resection of the tumor for diagnostic and therapeutic purposes. Clinical records were obtained to review patient data including patient's age, tumor cell type, histologic grade, tumor size, FIGO stage, lymphovascular invasion and lymph node metastasis. All specimens included in this study are obtained prior to chemotherapy or radiotherapy. The histopathologic diagnosis and grading of cancer cases were revised by the author. Investigated carcinomas were categorized into well-differentiated, moderately differentiated and poorly differentiated based on WHO classification of histologic differentiation. All carcinomas were staged according to International Federation of Gynecology and Obstetrics (FIGO) criteria. ${ }^{[11]}$ Age of patients ranged from 28-66 years with mean age $45.25 \pm 9.04$ years. The patient and tumor characteristics of investigated cases were shown in Table 1.

Immunohistochemical Staining: Immunohistochemical staining was performed on $4-\mu \mathrm{m}$ thick sections. These sections were immunostained with primary antibodies against SATB1 (dilution 1:100, rabbit monoclonal [clone EPR3951], Abcam, Cambridge, UK) and DJ-1 (dilution 1:100, mouse monoclonal [clone A-9], Santa Cruz
Biotechnology, Santa Cruz, CA, USA) along with DAKO universal LSAB2/HRP detection kit (DAKO, Glostrup, Denmark). Negative control was performed by omission of primary antibodies and replacement by PBS. Human tonsils served as positive control for SATB1 while human prostate was employed as positive control for DJ-1.

Interpretation of IHC Results: Positive immunostaining for SATB1 was nuclear and DJ-1 was cytoplasmic and nuclear. Positive cases were classified according to the rate of positive cell staining on one hand and their staining intensity on the other. Immunostaining in $<10 \%$ of tumor cells is categorized as 0 , immunostaining in $10-25 \%$ of tumor cells as 1 , staining in $26-50 \%$ of tumor cells as 2 , staining and staining $>50 \%$ as 3 . The staining intensity in each specimen was categorized as $0,1,2,3$ (negative, weak, moderate, or strong, respectively). The total immunostaining score was calculated by sum of the two above scores. Scores $\leq 2$ were regarded as negative expression and scores of 3-6 were regarded as positive expression.

Statistical Analysis: The statistical analyses were performed using SPSS for Windows, version 16.0 (SPSS Inc., Chicago, IL). Chi-square and Fisher's exact tests were used when appropriate to assess the relationships between biomarkers and clinicopathologic variables of included tumors. Two-sided $p$-values of $<0.05$ were considered significant.

\section{Result}

SATB1 Immunohistochemical Expression: SATB1 positive immunostaining was detected in 25 out of 60 cervical carcinomas $(41.7 \%)$ versus 3 out of 15 HSIL $(20 \%)$ and one case out of 15 LSIL $(6.7 \%)\left(X^{2}=7.962\right.$, $p=0.019)$. In carcinomas, positive immunoreactivity for SATB1was distributed as 22 out of $53 \mathrm{SCC}(41.5 \%)$ and 3 out of $7 \mathrm{AC}(42.9 \%)$. No immunostaining for SATB1 was noted in normal cervical tissue. Our study demonstrated a significant association between SATB1 expression and lymph node metastasis. The rate of positive SATB1 immunostaining in tumors with lymph nodal metastasis (12 out of 17 cases, $70.6 \%$ ) was higher than in those without nodal metastasis (13 out of 43 cases, $30.2 \%)\left(X^{2}=\right.$ $8.163, p=0.004)$. Also, a significant positive relationship was noted between positive SATB1 expression and higher TNM stages since SATB1 expression was detected in 14 out of 22 stage III tumors (63.6\%) while it was detected in 3 out of $13(23.1 \%)$ and in 8 out of 25 cases (32\%) stage I and II tumors, respectively $\left(X^{2}=7.178, p=0.028\right)$.

No significant relationship was observed between SATB1 expression and age $(p=0.861)$, histologic subtype $(p=$ 
$0.946)$, tumor grade $(p=0.190)$, tumor size $(p=0.315)$, and LVI $(p=0.241)$. (Table 2) (Figure 1, 2).

DJ-1immunohistochemical Expression: DJ-1 positive immunoreactivity was detected in 41 out of 60 investigated cancer cases $(68.3 \%)$ versus 5 out of 15 HSIL $(33.3 \%)$ and 2 out of $15 \operatorname{LSIL}(13.3 \%)\left(X^{2}=17.478, p=0.001\right)$. In carcinomas, positive immunostaining for DJ-1 was distributed as 37 out of $53 \mathrm{SCC}(69.8 \%)$ and 4 out of 7 AC (57.1\%). Dj-1 immunostaining in SIL cases was mainly cytoplasmic. Normal cervical tissue did not show any immunoreactivity to DJ-1. The present study demonstrated a significant positive association between DJ-1 expression and lymph node metastasis. The rate of positive DJ-1 expression was higher in tumors positive for nodal metastasis (15 out of 17 cases, 88.2\%) than in those negative for nodal metastasis (26 out of 43 cases, $60.5 \%)\left(X^{2}=4.342, p=0.037\right)$. Meanwhile, no significant relationship was observed between DJ-1 expression and age $(p=0.630)$, histologic subtype $(p=0.498)$, tumor grade $(p$ $=0.247)$, tumor size $(p=0.919)$, FIGO stage $(p=0.354)$ and LVI $(p=0.072)$. (Table 3) (Figure 3, 4)

The Relationship Between SATB1 and DJ1immunoreactivity: The present study demonstrated a significant positive relationship between SATB1 and DJ-1 immunoreactivity in investigated cervical carcinomas $\left(X^{2}=\right.$ $4.861, p=0.027)$.

Table 1: Tumor and Patients Characteristics.

\begin{tabular}{|l|l|l|}
\hline Characteristics & N & (\%) \\
\hline $\begin{array}{l}\text { Age at diagnosis (range 28-66 years; mean 45.25 } \pm 9.04 \text { years) } \\
\leq 45 \text { years }\end{array}$ & 28 & $(46.7)$ \\
$>45$ years & 32 & $(53.3)$ \\
\hline $\begin{array}{l}\text { Histologic types: } \\
\text { - Squamous cell carcinoma (SCC) }\end{array}$ & & \\
- Adenocarcinoma (AC) & 53 & $(88.3)$ \\
\hline $\begin{array}{l}\text { Tumor Differentiation } \\
\text { Well differentiated }\end{array}$ & 7 & $(11.7)$ \\
Moderately differentiated & 9 & $(15)$ \\
Poorly differentiated & 25 & $(41.7)$ \\
\hline Tumor Size & 26 & $(43.3)$ \\
\hline$\leq 4 \mathrm{~cm}$ & & \\
$>4 \mathrm{~cm}$ & 31 & $(51.7)$ \\
\hline pN status & 29 & $(48.3)$ \\
N0 & & \\
N1 & 43 & $(71.7)$ \\
\hline FIGO stage & 17 & $(28.3)$ \\
\hline II & & \\
III & 13 & $(21.7)$ \\
\hline LVI & 25 & $(41.7)$ \\
Negative & 22 & $(36.7)$ \\
Positive & & $(68.3)$ \\
\hline
\end{tabular}

$N=$ number,$(\%)=$ percentage; $p N$, lymph node status; : LVI, lymphovascular invasion

Table 2: SATB1 expression and clinicopathologic variables in cervical carcinomas.

\begin{tabular}{|l|c|c|c|}
\hline Variables & N & $\begin{array}{c}\text { Negative } \\
\mathbf{n}(\%)\end{array}$ & $\begin{array}{c}\text { Positive } \\
\mathbf{n}(\%)\end{array}$ \\
\hline Age & & & \\
$\mathbf{P}$
\end{tabular}




\begin{tabular}{|c|c|c|c|c|}
\hline Variables & $\mathbf{N}$ & $\begin{array}{c}\text { Negative } \\
\text { n (\%) }\end{array}$ & $\begin{array}{c}\text { Positive } \\
\text { n (\%) }\end{array}$ & $\mathbf{P}$ \\
\hline $\begin{array}{l}\text { Tumor Differentiation } \\
\text { Well differentiated } \\
\text { Moderately differentiated } \\
\text { Poorly differentiated }\end{array}$ & $\begin{array}{c}9 \\
25 \\
26\end{array}$ & $\begin{array}{c}7(77.8 \%) \\
16(64 \%) \\
12(46.2 \%)\end{array}$ & $\begin{array}{c}2(22.2 \%) \\
9(36 \%) \\
14(53.8 \%)\end{array}$ & 0.190 \\
\hline $\begin{array}{l}\text { Tumor Size } \\
\leq 4 \mathrm{~cm} \\
>4 \mathrm{~cm}\end{array}$ & $\begin{array}{l}31 \\
29\end{array}$ & $\begin{array}{l}20(64.5 \%) \\
15(51.7 \%)\end{array}$ & $\begin{array}{l}11(35.5 \%) \\
14(48.3 \%)\end{array}$ & 0.315 \\
\hline $\begin{array}{l}\text { pN status } \\
\text { Negative (N0) } \\
\text { Positive (N1) }\end{array}$ & $\begin{array}{l}43 \\
17\end{array}$ & $\begin{array}{c}30(69.8 \%) \\
5(29.4 \%)\end{array}$ & $\begin{array}{l}13(30.2 \%) \\
12(70.6 \%)\end{array}$ & 0.004 \\
\hline $\begin{array}{l}\text { FIGO stage } \\
\text { I } \\
\text { II } \\
\text { III }\end{array}$ & $\begin{array}{l}13 \\
25 \\
22\end{array}$ & $\begin{array}{c}10(76.9 \%) \\
17(68 \%) \\
8(36.4 \%)\end{array}$ & $\begin{array}{c}3(23.1 \%) \\
8(32 \%) \\
14(63.6 \%)\end{array}$ & 0.028 \\
\hline $\begin{array}{l}\text { LVI } \\
\text { Negative } \\
\text { Positive }\end{array}$ & $\begin{array}{l}41 \\
19\end{array}$ & $\begin{array}{c}26(63.4 \%) \\
9(47.4 \%)\end{array}$ & $\begin{array}{l}15(36.6 \%) \\
10(52.6 \%)\end{array}$ & 0.241 \\
\hline
\end{tabular}

Table 3: DJ-1 expression and clinicopathologic variables in cervical carcinomas.

\begin{tabular}{|c|c|c|c|c|}
\hline Variables & $\mathbf{N}$ & $\begin{array}{l}\text { Negative } \\
\mathrm{n}(\%)\end{array}$ & $\begin{array}{l}\text { Positive } \\
\text { n (\%) }\end{array}$ & $\mathbf{P}$ \\
\hline $\begin{array}{l}\text { Age } \\
\leq 45 \text { years } \\
>45 \text { years }\end{array}$ & $\begin{array}{l}28 \\
32\end{array}$ & $\begin{array}{l}8(28.6 \%) \\
11(34.4 \%)\end{array}$ & $\begin{array}{l}20(71.4 \%) \\
21(65.6 \%)\end{array}$ & 0.630 \\
\hline $\begin{array}{l}\text { Histologic subtype } \\
\text { - Squamous cell carcinoma } \\
\text { - Adenocarcinoma }\end{array}$ & $\begin{array}{l}53 \\
7\end{array}$ & $\begin{array}{l}16(30.2 \%) \\
3(42.9 \%)\end{array}$ & $\begin{array}{l}37(69.8 \%) \\
4(57.1 \%)\end{array}$ & 0.498 \\
\hline $\begin{array}{l}\text { Tumor Differentiation } \\
\text { Well differentiated } \\
\text { Moderately differentiated } \\
\text { Poorly differentiated }\end{array}$ & $\begin{array}{l}9 \\
25 \\
26\end{array}$ & $\begin{array}{l}5(55.6 \%) \\
7(28 \%) \\
7(26.9 \%)\end{array}$ & $\begin{array}{l}4(44.4 \%) \\
18(72 \%) \\
19(73.1 \%)\end{array}$ & 0.247 \\
\hline $\begin{array}{l}\text { Tumor Size } \\
\leq 4 \mathrm{~cm} \\
>4 \mathrm{~cm}\end{array}$ & $\begin{array}{l}31 \\
29\end{array}$ & $\begin{array}{l}10(32.3 \%) \\
9(31 \%)\end{array}$ & $\begin{array}{l}21(67.7 \%) \\
20(69 \%)\end{array}$ & 0.919 \\
\hline $\begin{array}{l}\text { pN status } \\
\text { Negative (N0) } \\
\text { Positive (N1) }\end{array}$ & $\begin{array}{l}43 \\
17\end{array}$ & $\begin{array}{l}17(39.5 \%) \\
2(11.8 \%)\end{array}$ & $\begin{array}{l}26(60.5 \%) \\
15(88.2 \%)\end{array}$ & 0.037 \\
\hline $\begin{array}{l}\text { FIGO stage } \\
\text { II } \\
\text { II } \\
\text { III }\end{array}$ & $\begin{array}{l}13 \\
25 \\
22\end{array}$ & $\begin{array}{l}6(46.2 \%) \\
8(32 \%) \\
5(22.7 \%)\end{array}$ & $\begin{array}{l}7(53.8 \%) \\
17(68 \%) \\
17(77.3 \%)\end{array}$ & 0.354 \\
\hline $\begin{array}{l}\text { LVI } \\
\text { Negative } \\
\text { Positive }\end{array}$ & $\begin{array}{l}41 \\
19\end{array}$ & $\begin{array}{l}16(39 \%) \\
3(15.8 \%)\end{array}$ & $\begin{array}{l}25(61 \%) \\
16(84.2 \%)\end{array}$ & 0.072 \\
\hline
\end{tabular}




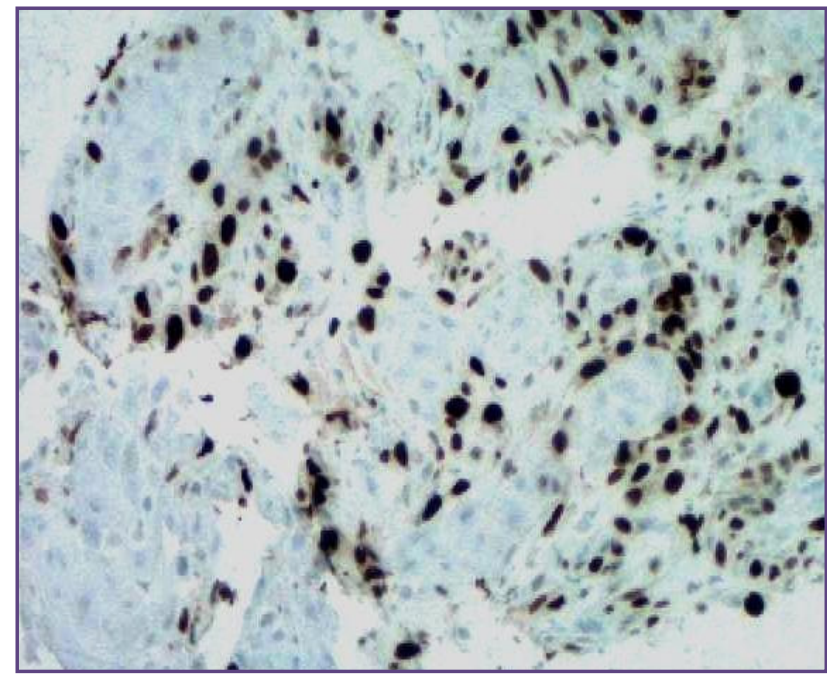

Fig. 1: SATB1 immunostaining in cervical squamous cell carcinoma $\mathbf{x} 20$.

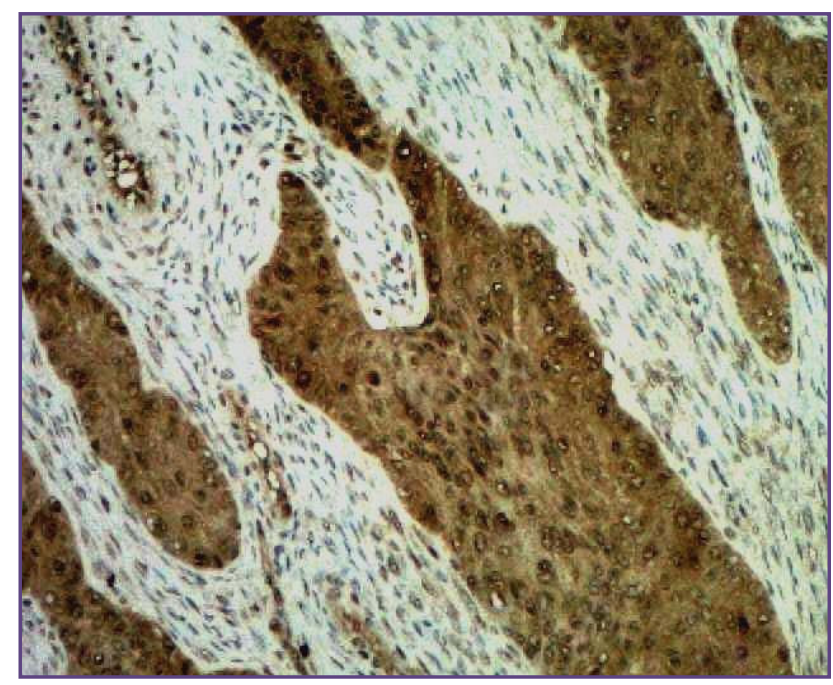

Fig. 3: DJ-1 immunostaining in cervical squamous cell carcinoma $\mathbf{x 2 0}$.

\section{Discussion}

SATB1 represents a novel class of transcription regulators as it functions as master genome organizer. SATB1 participates in the maintenance and compaction of chromatin architecture by organizing it into distinct loops via periodic anchoring of matrix attachment regions (MARs) to the nuclear matrix. ${ }^{[4]}$ Also, SATB1 can regulate distant genes by selectively tethering MARs to the nuclear matrix resulting in the formation of a characteristic 'cagelike' network that circumscribes heterochromatin. ${ }^{\text {4- }}$ 6,12,13] Moreover, SATB1 seems to serve two different but related purposes, structurally as a component of chromatin architecture and functionally as a transcription factor via binding to the upstream regulatory elements and recruiting

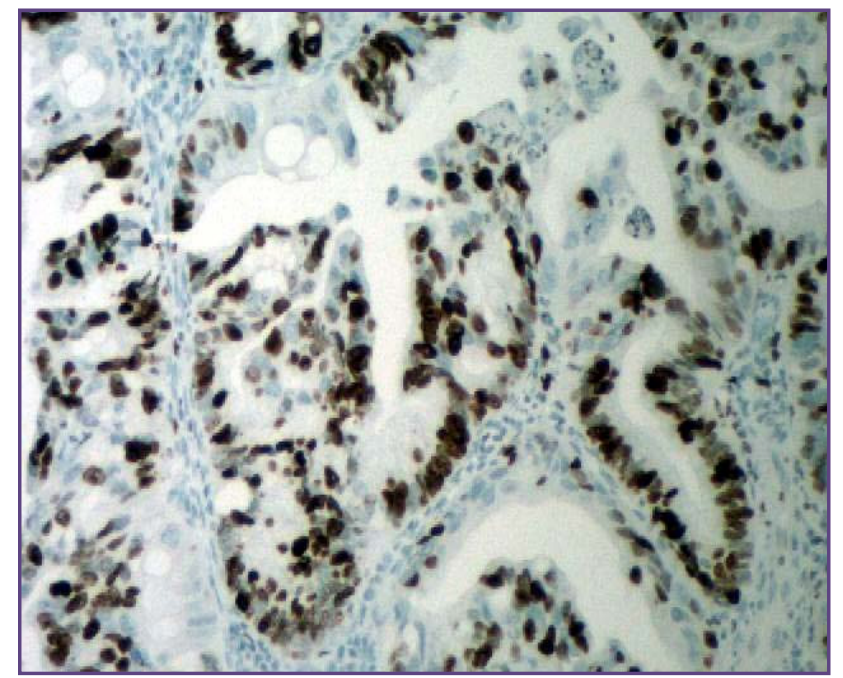

Fig. 2: SATB1 immunostaining in cervical adenocarcinoma $\mathrm{x} 20$.

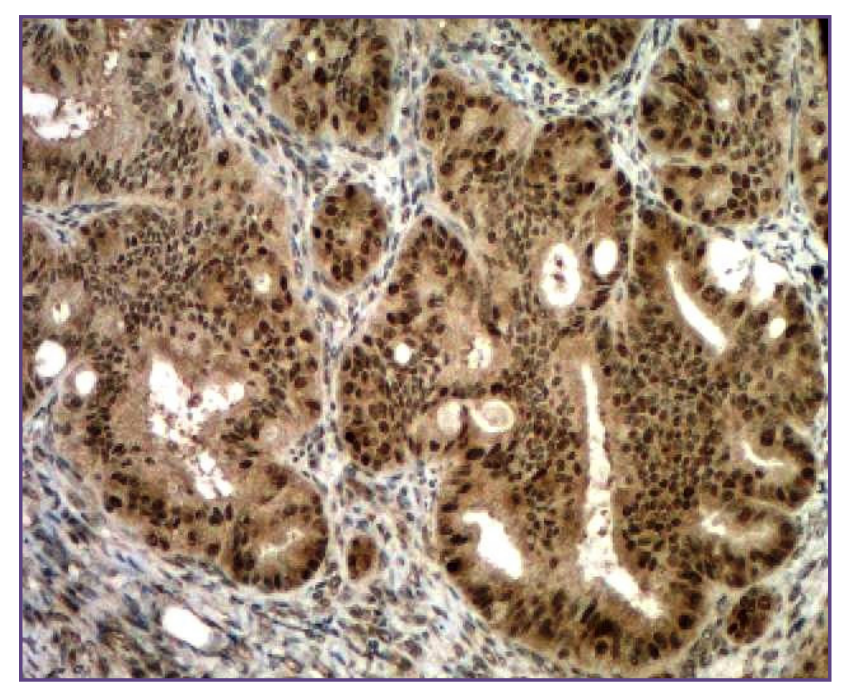

Fig. 4: DJ-1 immunostaining in cervical adenocarcinoma x20.

chromatin remodeling enzymes. ${ }^{[4,5,14]}$ Recently, SATB1 was shown to provide a nuclear architectural platform regulating the expression of $>1000$ genes involved in many biologic processes, including proliferation, apoptosis, cell cycle, cell adhesion, signaling, extacellular matrix formation and epithelial-mesenchymal transition, indicating a potential role of SATB1 in malignant transformation and progression. ${ }^{[14]}$ This role was demonstrated in breast and prostate cancer cell lines as when SATB1 gene was transfected into non-aggressive cell lines of these cancers; these cells acquired aggressive phenotype with invasion and metastasis characteristics. On the contrary, silencing of the SATB1 gene in the aggressive cancer cell lines inhibited the tumor growth, invasion and metastasis. ${ }^{[13,14]}$ SATB1 
appears to orchestrate specific epigenetic modifications at target gene loci by directly upregulating metastasisassociated genes while downregulating tumour-suppressor genes. ${ }^{[14]}$ In correspondence with these biologic effects, SATB1 overexpression and its association with advanced clinicopathologic variables and poor prognosis have been reported in a variety of malignant tumors including breast, prostate, gastric, colorectal, liver, ovarian and laryngeal carcinomas in addition to malignant melanoma. ${ }^{[0,12-20]}$ In agreement with these reports, the present study has demonstrated a significant positive association between SATB1 overexpression and advanced clinicopathologic parameters of cervical carcinoma including lymph node metastasis and higher FIGO stage. Our results are consistent with those of a single recent study which was conducted by Wang and his colleagues in China on 167 cervical SCC and demonstrated a significant correlation of SATB1 expression with lymph node metastasis and FIGO stage in addition to histologic grade, lymphovascular invasion and recurrence. ${ }^{[2]} \mathrm{Up}$ to our knowledge, no more studies concerning SATB1 expression and clinicopathologic variables in cervical cancer are available in literature so far.

DJ-1 plays a crucial role in tumorigenesis, tumor cell survival, proliferation, invasion and metastasis. There are multiple molecular mechanisms underlying DJ-1 biological effects. DJ-1 upregulates PI3K/AKT/mTOR signaling pathway and its downstream effectors through negative regulation of PTEN tumor suppressor gene expression leading to removal of the inhibitory effect of PTEN on PI3K/AKT/mTOR pathway, thereby promoting cell viability, growth and proliferation. ${ }^{[9,10]}$

Recent studies have also shown that DJ-1 promotes tumor cells invasion and migration by activating urokinase plasminogen activator (uPA) system and matrix metalloproteinase-2 (MMP2) through the SRC/ ERK pathway. ${ }^{[21]}$ Moreover, DJ-1 enhances epithelialmesenchymal transition (EMT) and cell invasion capacity by downregulating E-cadherin, KLF17 and increasing Snail expression. ${ }^{[7]}$

Also, DJ-1 has been shown to promote survival of tumor cells by providing them a protection against hypoxiainduced cell death and increasing their adaptation to severe hypoxic stress through several mechanisms including upregulation of AMP-activated protein kinase (AMPK) pathway, negative regulation of p53-dependent proapoptotic gene expression programs that are activated under hypoxia and finally through stabilization of hypoxiainducible factor-1 $\alpha$ (HIF-1 $\alpha)$ partly via upregulation of PI3K/AKT/mTOR pathway and partly via inhibition of
Von Hippel Lindau (VHL) -induced degradation of HIF$1 \alpha .{ }^{[22]}$ Additionally, DJ-1 has been reported to inhibit apoptosis through upregulation of survivin anti-apoptotic gene and suppression of both tumor necrosis factor-related apoptosis-inducing ligand (TRAIL)-induced apoptosis and p53-Bax-caspase pathway. ${ }^{[23,24]}$

Consistent with these biologic activities, DJ-1 overexpression along with its association with tumor progression and poor outcome has been reported in several malignancies including non-small cell lung carcinoma, laryngeal squamous cell carcinoma as well as gastric, pancreatic, urothelial, breast and endometrial carcinomas. $[7,10,23-26]$

In concordance with these reports, the present study demonstrated DJ-1 overexpression in cervical cancer where it was associated with lymph node metastasis. Up to our knowledge, limited data is available in the literature regarding DJ-1 expression in cervical cancer. However, our findings are consistent with a recent Chinese study (its abstract is available online in English) which demonstrated a significant correlation between DJ-1 overexpression and lymph node metastasis as well as higher tumor grade in cervical squamous cell carcinoma. ${ }^{[27]}$ Otherwise, two more studies have demonstrated significant higher level of DJ-1 expression in cervical carcinoma tissue versus normal cervical tissue which was noted in our study but none of them has studied the relationship between biomarker expression and clinicopathologic variables. ${ }^{[28,29]}$ Our findings regarding DJ-1 overexpression in cervical cancer could be supported by the finding that transfection of nonmetastatic cancer cell lines by DJ-1 has increased their invasion capacity ${ }^{[7]}$ On the contrary, knocking down of DJ-1 by small interfering RNA (siRNA) in breast, endometrial, cervical, pancreatic, and laryngeal carcinoma cell lines has led to impaired cancer cell viability, proliferation, invasion and migration in addition to enhanced sensitivity of tumor cells to chemotherapeutic drugs. ${ }^{[7,9,21,24,29]}$

\section{Conclusion}

The present study has pointed out the possible role of SATB1 and DJ-1 in cervical carcinogenesis as shown by complete absence of their expression in normal cervical tissue along with significant increase in the expression of both biomarkers upon progression from SIL to carcinoma. Also, SATB1 and DJ-1 are shown to be promising potential prognostic biomarkers in cervical carcinoma since their overexpression is correlated with advanced clinicopathologic variables including lymph node metastasis. A significant positive association between SATB1 and DJ-1 immunoreactivity was detected in 
investigated cervical carcinomas. Our findings suggest SATB1 and DJ-1 to be promising therapeutic targets for cervical cancer.

\section{Reference}

1. Ferlay J, Soerjomataram I, Ervik M, Dikshit R, Eser S, Mathers C, et al. GLOBOCAN 2012 v1.0, Cancer Incidence and Mortality Worldwide: IARC Cancer Base No. 11 [Internet]. Lyon, France: International Agency for Research on Cancer; 2013. Available from: http://globocan.iarc.fr.

2. Wang S, Wang L, Zhang Y, Liu Y, Meng F, Ma J, et al. Special AT-rich sequence-binding protein 1: a novel biomarker predicting cervical squamous cell carcinoma prognosis and lymph node metastasis. Jpn J Clin Oncol. 2015; 45(9):812818.

3. Alvarez JD, Yasui DH, Niida H, Joh T, Loh DY, KohwiShigematsu T: The MAR-binding protein SATB1 orchestrates temporal and spatial expression of multiple genes during T-cell development. Genes Dev. 2000; 14:521535 .

4. Cai S, Han HJ, Kohwi-Shigematsu T. Tissue-specific nuclear architecture and gene expression regulated by SATB1. Nat Genet. 2003; 34:42-51.

5. Galande S, Purbey PK, Notani D, Kumar PP: The third dimension of gene regulation: organization of dynamic chromatin loopscape by SATB1. Curr Opin Genet Dev. 2007; 17:408-414.

6. Zhang S, Gao X, Ma Y, Jiang J, Dai Z, Yin X, et al. Expression and significance of SATB1 in the development of breast cancer. Genet Mol Res. 2015; 14(2):3309-3317.

7. Ismail IA, Kang HS, Lee HJ, Kim JK, Hong SH. DJ-1 upregulates breast cancer cell invasion by repressing KLF17 expression. Br J Cancer 2014; 110:1298-1306.

8. Wang B, Qin H, Wang Y, Chen W, Luo J, Zhu X, et al. Effect of DJ-1 overexpression on the proliferation, apoptosis, invasion and migration of laryngeal squamous cell carcinoma SNU-46 cells through PI3K/AKT/mTOR. Oncol Rep. 2014; 32(3):1108-1116.

9. Cao J, Lou S, Ying M, Yang B. DJ-1 as a human oncogene and potential therapeutic target. Biochemical Pharmacology 2015; 93: 241-250.

10. Kim RH, Peters M, Jang Y, Shi W, Pintilie M, Fletcher $\mathrm{GC}$, et al. DJ-1, a novel regulator of the tumor suppressor PTEN. Cancer Cell 2005; 7: 263-273.

11. Kurman RJ, Caracangiu ML, Herrington CS and Young RH, "World Health Organization Classification of Tumors: WHO Classification of Tumors of Female Reproductive Organs", 4th edition, Lyon: IARC press, 2014; pp 170-171.

12. Patani N, Jiang W, Mansel R, Newbold R, Mokbel K. The mRNA expression of SATB1 and SATB2 in human breast cancer. Cancer Cell Int. 2009; 9:18.
13. Mao L, Yang C, Wang J, Li W, Wen R, Chen J, et al. SATB1 is overexpressed in metastatic prostate cancer and promotes prostate cancer cell growth and invasion. J Transl Med. 2013; 11:111.

14. Han HJ, Russo J, Kohwi Y, Kohwi-Shigematsu T: SATB1 reprogrammes gene expression to promote breast tumour growth and metastasis. Nature 2008; 452(7184):187-193.

15. Lu X, Cheng C, Zhu S, Yang Y, Zheng L, Wang G, et al. SATB1 is an independent prognostic marker for gastric cancer in a Chinese population. Oncol Rep. 2010; 24(4):981987.

16. Zhang Y, Tian X, Ji H, Guan X, Xu W, Dong B, et al. Expression of SATB1 promotes the growth and metastasis of colorectal cancer. PLoS One. 2014; 9(6):e100413.

17. Wu D, Zeng L, Liu F, Zhong Q, Zhang D, Cai C, et al. Special AT-rich DNA-binding protein-1 expression is associated with liver cancer metastasis. Oncol Lett. 2016; 12(6):4377-4384.

18. Xiang J, Zhou L, Li S, Xi X, Zhang J, Wang Y, et al. ATrich sequence binding protein 1: contribution to tumor progression and metastasis of human ovarian carcinoma. Oncol Lett. 2012; 3(4):865-870.

19. Zhao XD, Ji WY, Zhang W, He LX, Yang J, Liang HJ, et al. Overexpression of SATB1 in laryngeal squamous cell carcinoma. ORL J Otorhinolaryngol Relat Spec. 2010; 72(1):1-5.

20. Chen H, Takahara M, Oba J, Xie L, Chiba T, Takeuchi S, et al. Clinicopathologic and prognostic significance of SATB1 in cutaneous malignant melanoma. J Dermatol Sci. 2011; 64(1):39-44.

21. He X, Zheng Z, Li J, Ben Q, Liu J, Zhang J, et al. DJ-1 promotes invasion and metastasis of pancreatic cancer cells by activating SRC/ERK/uPA. Carcinogenesis. 2012; 33(3):555-562.

22. Vasseur S, Afzal S, Tardivel-Lacombe J, Park DS, Iovanna JL, Mak TW. DJ-1/PARK7 is an important mediator of hypoxia-induced cellular responses. Proc Natl Acad Sci U S A. 2009; 106:1111-1116.

23. Shen Z, Ren Y, Ye D, Guo J, Kang C, Ding H. Significance and relationship between DJ-1 gene and surviving gene expression in laryngeal carcinoma. Eur J Histochem. 2011; 55:e9.

24. Shu K, Xiao Z, Long S, Yan J, Yu X, Zhu Q, Mei T. Expression of DJ-1 in endometrial cancer close correlation with clinicopathological features and apoptosis. Int $\mathrm{J}$ Gynecol Cancer. 2013; 23:1029-35.

25. Li Y, Cui J, Zhang CH, Yang DJ, Chen JH, Zan WH, et al. High-expression of DJ-1 and loss of PTEN associated with tumor metastasis and correlated with poor prognosis of gastric carcinoma. Int J Med Sci. 2013; 10:1689-1697. 
26. Lee H, Choi SK, Ro JY. Overexpression of DJ-1 and HSP90 $\alpha$, and loss of PTEN associated with invasive urothelial carcinoma of urinary bladder: Possible prognostic markers. Oncol Lett. 2012; 3:507-512.

27. Sun Y-H, Wen W, Song J-M, Xu M-Q, Yang Z-Y. Expression of DJ-1 in human cervical lesion tissues and its clinical significance. Chinese J. Diagn. Pathol. 2013; 3. Abstract (available in English on website: en.cnki.com.cn/Article_en/
CJFDTOTAL-ZDBL201303014.htm).

28. Arnouk H, Merkley MA, Podolsky RH, Stöppler H, Santos C, Alvarez M, et al. Characterization of Molecular Markers Indicative of cervical Cancer Progression. Proteomics Clin Appl. 2009; 3:516-527.

29. Wang H, Gao W. DJ-1 Expression in Cervical Carcinoma and its Effects on Cell Viability and Apoptosis. Med Sci Monit, 2016; 22: 2943-2949.

*Corresponding author:

Ashraf Ishak Fawzy Tawadros (Lecturer of pathology) Pathology Department, Faculty of Medicine, Minia University, El Minia, Egypt

Phone: +91 02-01207746686

Email: ash_han2012@yahoo.com

Financial or other Competing Interests: None. 